\title{
Esensi Reward dan Punishment dalam Diskursus Pendidikan Agama Islam
}

\author{
Firdaus* \\ Universitas Islam Riau, Indonesia \\ Jl. Kaharuddin Nst No.113, Simpang Tiga, Kec. Bukit Raya, Kota Pekanbaru, Riau 28284 \\ Email: firdausrida@edu.uir.ac.id
}

\begin{abstract}
This study aims to determine the essence of a reward and punishment in the world of education. Mistakes in giving rewards and punishments sometimes make pedagogical interactions breakdown between teachers and students. The method used in this study is qualitative research with a library research approach. Because this research is in the form of library research, the data is taken from book or journal sources related to this research. The findings in this study are that in using the reward and punishman methods, they must follow the signs and also the existing rules. Giving rewards and punishments that do not follow the rules will cause a conflict between students and students even between students and teachers themselves. In giving rewards must be purely as motivation for students. Motivation that delivers is far better in undergoing the process of teaching and learning. Likewise in giving punishment to students it must be done in an effort to prevent from doing wrong and negligence.
\end{abstract}

Keyword: Reward, Punishment, Islamic Education

Abstrak: Penelitian ini bertujuan untuk mengetahui esensi sebuah reward dan punishment dalam khazanah pendidikan Islam. Kesalahan dalam memberikan reward dan punishment terkadang membuat rusaknya interaksi pedagogis antara guru dan juga siswa. Metode yang digunakan dalam penelitian ini adalah penelitain kualitatif dengan pendekatan library research. Karena penelitian ini dalam bentuk penelitian pustaka, maka data diambil dari sumber-sumber buku ataupun jurnal yang berkaitan dengan penelitian ini. Hasil temuan dalam penelitian ini adalah bahwa dalam menggunakan metode reward dan punishman haruslah mengikuti rambu-rambu dan juga aturanaturan yang ada. Pemberian reward dan punishment yang tidak mengikuti aturan akan menimbulkan suatu konflik antara siswa dan siswa bahkan antara siswa dengan guru itu sendiri. Dalam pemberian reward haruslah murni sebagai motivasi bagi peserta didik. Motivasi yang mengantarkan jauh lebih baik dalam menjalani proses belajar mengajar. Demikian pula dalam pemberian punishment kepada peserta didik haruslah dilakukan dalam upaya pencegahan dari berbuat salah dan kelalaian.

Kata Kunci: Reward, Punishment, Pendidikan Islam

Jurnal Pendidikan Agama Islam Al-Thariqah Vol. 5, No. 1, Januari - Juni 2020

Received: 30 April 2020; Accepted 08 June 2020; Published 21 June 2020

*Corresponding Author: firdausfrida@edu.uir.ac.id 


\section{PENDAHULUAN}

Dalam Islam pendidikan memiliki kedudukan yang penting bagi manusia. Karena dengan pendidikan manusia akan mengetahui jati dirinya dan juga akan mengetahui hakikat hidup yang dijalani dimuka bumi ini. Begitu pentingnya pendidikan bagi manusia, maka pendidikan tersebut tidaklah dapat dipandang sebelah mata, atau pendidikan tersebut hanya dijadikan pelengkap bagi kehidupan manusia.

Pendidikan merupakan suatu yang sangat urgen yang harus diperhatikan dengan mengerahkan segenap kemampuan kita. Karena melalui pendidikan pulalah kualitas manusia tersebut akan dapat diukur apakah dia menjadi seorang yang mengabdikan dirinya kepada Allah SWT atau bahkan dia menjadi seseorang yang menentang Allah SWT.

Salah satu usaha untuk mencapai keberhasilan dalam pendidikan adalah dengan menerapkan kedisiplinan kepada para murid. Tanpa adanya suatu kedisiplinan yang tinggi maka hasil dari suatu pendidikan tidak akan dapat kita capai. Menurut Hurlock dalam Rusydiana Hamid, secara umum konsep disiplin adalah sama dengan punishment (Rusydiana, 2006: 66). Penegakan kedisiplinan tersebut diperlukan jika adanya gejala-gejala pelaggaran yang dilakukan oleh peserta didik.

Kedisiplinan diterapkan bukanlah untuk memberatkan apalagi membebani peserta didik. Kedisiplinan bertujuan untuk pembentukan karakter dan juga membimbing mereke pada pembentukan tingkah laku yang lebih baik lagi.

Pendisiplinan yang diterapkan kepada peserta didik diperlukan suatu pengawasan yang dilakukan oleh guru ataupun pihak-pihak yang terkait. Tanpa adanya pengawasan yang baik, maka kedisipilnan tersebut tidak akan dapat berjalan dengan baik. Sehingga ramburambu kedisiplinan tersebut hanya sebatas aturan-aturan yang tertulis dilembaran-lembaran kertas.

Berbicara masalah kedisiplinan pada peserta didik, maka akan kita dapati siswa yang memiliki komitmen tinggi terhadap aturan-aturan yang telah disepakati bersama. Dan ada pula siswa yang menganggap remeh aturan yang telah disepakati tersebut.

Permasalahan ini adalah masalah yang sangat besar dalam bidang pendidikan. Pelanggaran-pelanggaran yang dilakukan oleh siswa dan diabaikan oleh guru ataupun pihak sekolah akan memberikan dampak negatif bagi siswa yang lain. Pelanggaran ataupun tindakan indisipliner yang dibiarkan akan menimbulkan ketidakstabilan dalam proses belajar mengajar maupun lingkungan sekolah itu sendiri.

Untuk itulah guru ataupun sekolah harus dapat menegakkan peraturanperaturan tersebut untuk menjaga kestabilan dalam proses belajar mengajar dengan memberikan punishment bagi pelanggar aturan dan memberikan reward bagi siswa yang berprestasi.

Penerapan punishment hendaknya dibarengi pemberian reward. Jika punishment bertujuan sebagai pencegahan suatu kelalaian peserta didik, maka reward diberikan sebagai motivasi dan juga penghargaan yang diberikan kepada siswa.

Reward dan punishmen, keduaduanya bertujuan untuk memperbaiki siswa dalam proses belajar mengajar. Hanya saja sudah tepatkah kita menggunakan reward dan punishment ini sebagai metode dalam pendidikan.

\section{KONSEP TEORI}

Reward merupakan pemberian penghargaan ataupun hadiah kepada peserta didik yang memiliki sebuah prestasi atau kelebihan-kelebihan yang lain yang dimilikinya dan tidak dimiliki oleh peserta didik yang lainnya (Rusdiana Hamid, 2006: 67). 
Dalam dunia pendidikan reward dijadikan sebagai alat untuk memberikan motivasi kepada siswa agar siswa tersebut giat dalam belajar dan menimbulkan sifat bersaing yang sehat antara satu siswa dengan siswa yang lainnya.

Dalam memberikan reward, seorang pendidik harus menyesuaikan dengan apa yang telah dicapai oleh peserta didik, jangan sampai pemberian reward tersebut menimbulkan sifat materalis pada diri peserta didik (Rusdiana Hamid, 2006: 68).

Pemberian reward yang berlebihan akan menghilangkan tujuan dari reward itu sendiri. Apa lagi dengan pemberian reward tersebut telah dianggap suatu upah oleh peserta didik.

Dalam pemberian reward sangatlah variatif, reward dapat diberikan berupa materi dan juga dapat diberikan berupa non materi (Wahyudi Setiawan, 2018: 187). Pemberian reward yang berupa materi dapat diwujudkan dengan hadiah ataupun benda-benda yang memiliki daya tarik terhadap siswa sehingga siswa termotivasi untuk mendapatkannya.

Adapun reward yang berupa non materi dapat berupa pujian, ataupun tepukan dipunggung dan hal-hal yang dapat menyenangkan hati siswa tersebut.

Adapun punishment adalah pemberian hukuman kepada siswa sebagai sebuah konsekwensi logis atas pelanggaran yang telah diperbuatnya dalam rangka pencegahan atas pelanggaran tersebut ataupun pemberi pembelajaran kepada yang lainnya (Baroroh, 2018: 55).

Dalam penjatuhan sebuah punishment seorang guru harus berhatihati dan harus sangat memperhatikan kondisi psikis seorang anak. Hal tersebut dilakukan agar punishment tersebut tidak menimbulkan dampak negatif pada diri peserta didik.

Pemberian punishment apalagi yang berupa fisik hendaklah dijadikan metode yang terakhir. Pendidik haruslah mencari alternatif yang lainnya sebelum memberikan hukuman kepada peserta didik. Setelah menggunakan pendekatanpendekatan yang lain ternyata tidak menemui hasil, maka guru dapat menggunakan pendekatan punishment kepada peserta didik.

Dalam pemberian sanksi berupa hukuman, terutama hukuman fisik maka hendaknya seorang pendidik tidak terburu-buru dan tidak terkesan pada balas dendam (Bafadhol, 2017: 1119).

Pemberian hukuman yang terburuburu ataupun cenderung untuk membalas dendam atas kesalahan siswa tadi akan menimbulkan efek yang tidak baik bagi siswa dan menjadikan hubungan antara siswa dan guru tersebut tidak baik.

Dalam pemberian reward dan punishment tersebut guru benar-benar harus memperhatikan kaidah-kaidah pendidikan. hal tersebut dilakukan untuk menghilangkan stigma negatif dari reward ataupun punishment tersebut.

\section{METODE PENELITIAN}

Penelitian ini menggunakan metode library research atau penelitian kepustakaan. Penelitian kepustakaan ini merupakan serangkaian kegiatan mengumpulkan data baik dari buku-buku ataupun sumber-sumber yang lainnya serta mengolah data-data tersebut (Zed. M, 2004: 3).

Data yang dikumpulkan dalam penelitian ini terbagi atas data primer dan juga data sekunder. Data primer didapat dari buku-buku ataupun jurnal yang membahas tentang reward dan punishment secara langsung seperti pada jurnal Serambi Tarbawi dengan judul Urgensi Reward dan Punishmen. Penulis juga mengambil dari jurnal al-Ibroh dengan judul artikel Pemberian hukuman dalam Perspektif Pendidikan Islam.

Adapun data sekunder penulis mengambilnya dari buku ataupun jurnal yang membahas masalah pendidikan 
secara umum. Ataupun buku-buku atau jurnal yang teori-teorinya dapat menunjang penelitian ini seperti buku Ilmu Pendidikan Teoritis dan Praktis karangan Ngalim Purwanto.

Tahapan dalam penelitian ini adalah dengan mengumpulkan data dan teori dari data primer dan sekunder tersebut. Selanjutnya bahan dan data tersebut dikaji, dicatat dan diinfentarisir dan dimanfaatkan sebaik-baiknya. Setelah semua tahapannya tuntas barulah datadata tersebut dianalisa. Analisa dalam penelitian ini adalah analisa deskriptif. Dalam analisa deskriptif ini peneliti memaparkan keterangan-keterangan yang menjadi objek data. Selanjutnya data tersebut dianalisa dengan menggunalakan analisis sintesis.

Pada analisis sintesis ini penulis berusaha untuk menganalisa suatu teori ataupun tulisan dalam rangka mendapatkan jawaban dari suatu permasalahan mengenai asal asal usul dari sesuatu dan apa yang menjadi penyebabnya dari yang bersifat umum kepada sesuatu yang bersifat khusus.

Selanjutnya peneliti juga menggunakan heuristik. Heuristik adalah merupakan langkah-langkah umum yang digunakan peneliti dalam rangka menemukan solusi suatu permasalahan (Lidinillah DAM, 2011: 1). Heuristik ini dilakukan secara mendalam terhadap halhal yang berkaitan dengan analisis. Sehingga peneliti menemukan sesutau yang baru dari apa yang sedang diteliti.

\section{HASIL DAN PEMBAHASAN \\ Reward dalam Pendidikan Islam}

Dalam dunia pendidikan kita mengenal istilah reward, yang mana reward ini termasuk salah satu metode dalam pendidikan. Reward merupakan suatu yang terpenting dalam rangka memotivasi peserta didik untuk memotivasi dalam belajar ataupun melakukan kebaikan-kebaikan lainnya (Setiawan., 2018: 186).
Reward diberikan kepada anak yang berhasil dalam melakukan kebaikan ataupun prestasi dalam kehidupannya sehari-hari baik prestasi tersebut dilingkungan sekolah, keluarga ataupun masyarakat.

Pentingnya reward kepada peserta didik disebabkan penghargaan tersebut menjadi suatu motivasi ataupun penggerak bagi manusia untuk melaksanakan atau mengaktualisasikan diri sebagai manusia.

Reward ataupun penghargaan merupakan suatu bentuk pengapresasian terhadap kebaikan yang telah diperbuat oleh seseorang. Yang mana tujuannya adalah sebagai motivasi agar orang yang mendapatkan penghargaan tersebut akan selalu berbuat kebaikan diwaktu lain.

Reward yang diberikan kepada peserta didik merupakan motivasi ekstrinsik yang berfungsi untuk merangsang anak yang bersangkutan ataupun peserta didik yang lainnya agar terbiasa untuk selalu berbuat kebaikan.

Menurut suatu penelitian pemberian reward kepada siswa sangat efektif dalam rangka meningkatkan hasil belajar (Setiawan, 2018: 189). Hal ini disebabkan oleh fitrah manusia itu sendiri yang membutuhkan suatu penghargaan dari orang lain.

Selain sebagi motivasi, reward yang diberikan kepada peserta didik juga dapat dijadikan sebagai alat untuk mengasah potensi-potensi kebaikan yang ada pada peserta didik (Bafadol, 2017).

Seperti yang kita ketahui bahwa dalam diri manusia terdapat dua potensi. potensi untuk beriman kepada Allah yang ditandai dengan giatnya seseorang untuk beramal sholeh dan juga potensi untuk mendurhakai dengan banyaknya orang bermaksiat kepada Allah SWT.

Agar potensi untuk beriman kepada Allah SWT selalu ada pada diri manusia maka potensi tersebut perlu untuk dikembangkan dan juga dilestarikan pada diri manusia. Agar potensi baik selalu 
berkembang maka diperlukanlah reward agar anak didik tersebut selalu berbuat kebajikan. Adapun reward yang diberikan kepada siswa tidak hanya berupa benda semata. Dalam dunia pendidikan pujian yang diberikan guru terhadap peserta didik merupakan penghargaan berharga.

Pemberian pujian atas prestasi ataupun keberhasilan kepada siswa merupakan suatu perhatian yang diberikan guru kepada anak didiknya. Secara tidak langsung pujian tersebut juga merupakan komunikasi ataupun tanggapan positif yang telah diberikan guru kepada siswanya. Dengan adanya komunikasi seperti itu maka siswa akan merasa diperhatikan oleh gurunya, sehingga mereka menganggap apa yang telah mereka lakukan tidaklah sia-sia.

Dengan memberikan pujian kepada siswanya berarti seorang guru telah membangun suatu komunikasi positif terhadap anak didiknya yang telah berhasil sekaligus memberikan pesan kepada murid yang lain untuk berbuat seperti yang diperbuat oleh murid yang mendapatkan reward tadi.

Dalam pemberian pujian hendaknya seorang guru menggunakan cara-cara yang khusus dan terukur, tidak terlalu berlebihan dan hendaknya sesuai dengan apa yang telah dilakukan oleh siswa (Salminawati, 2019: 2).

Pemberian pujian yang berlebihan dan tidak sesuai dengan apa yang dilakukan oleh anak didik akan mengakibatkan anak didik tersebut "besar kepala" dan merasa superior dari teman-temannya yang lain. Pemberian pujian yang berlebihan juga akan mengakibatkan kecemburuan sosial bagi murid-murid yang lainnya. Apabila hal ini terjadi maka reward tidaklah lagi menjadi alat yang positif dalam dunia pendidikan.

Kecemburuan siswa yang lain dikarenakan guru memuji temannya secara berlebihan akan menciptakan gap atau jarak antara siswa-siswi dan guru itu sendiri.
Jika guru memberikan reward berbentuk materi (barang) yang harus diperhatikan guru kepada siswanya adalah bahwa materi ataupun barang yang dijadikan reward tersebut bukanlah satu-satunya tujuan. Jadi guru harus dapat memberikan pemahaman bahwa hadiah yang diberikan tersebut hanya merupakan suatu motivasi dan bukan tujuan. Jika materi ataupun barang tersebut menjadi tujuan siswa, maka guru lebih baik untuk menunda pemberian reward tersebut.

Situasi kondisi dan keadaan siswa sangat perlu untuk diperhatikan sebelum guru memberikan hadiah atau ganjaran kepada siswanya. Jika siswa dalam keadaan normal dan dipandang tidak perlu untuk memberikan reward, maka reward yang berupa benda tersebut tidak perlu untuk diberikan. Guru bisa memberikan reward yang bukan berupa benda seperti pujian. Hal seperti ini perlu untuk menjadi perhatian guru agar siswa tersebut tidak menjadikan reward/hadiah tersebut sebagai satu-satunya tujuan dalam belajar. Selain itu hal seperti ini perlu dihindari agar anak didik tersebut melakukan sesuatu hal bukan dikarenakan upah yang akan diterimanya.

Kemudian jika reward yang diberikan berupa barang, maka sebaiknya barang tersebut harus menarik dan berkesan sehingga peserta didik ketika menerimanya meresa gembira. Bila guru memberikan reward yang tidak sesuai dengan kegemaran mereka, tentu efektivitas pemberian reward tersebut tidak dapat mencapai tujuan. Selain itu, hadiah tersebut juga haruslah dalam batas kewajaran dan seperlunya dan tidak diberikan secara terus menerus. Pemberian hadiah yang kontiniu dan dilakukan secara terus menerus akan menjadikan peserta didik matrealistis. Sementara sifat materialistik ini sangat tidak baik bagi seorang peserta didik. 


\section{Urgensi Reward dalam Pendidikan Islam}

Reward yang diberikan dengan benar dan memperhatikan etika-etika dalam pemberian reward akan mampu meningkatkan motivasi belajar peserta didik. Metode reward juga memiliki efektifitas yang tinggi pada peserta didik untuk mendapatkan hasil yang maksimal dalam proses belajar mengajar (Akyuni, 2013: 57).

Motivasi yang diberikan guru kepada siswa akan berimplikasi pada hasil belajar yang optimal pada anak didik. Sebaliknya bagi anak didik yang membutuhkan motivasi dari gurunya, dan motivasi tersebut tidak didapatkannya maka akan memberikan implikasi yang negatif terhadap hasil belajar dan juga proses belajar mengajar itu sendiri.

Bagi seorang pendidik pemberian reward kepada anak didiknya adalah sebuah ungkapan kepuasan seorang guru terhadap hasil positif yang telah didapai oleh anak didiknya. Sehingga anak didikpun mengetahui bahwa gurunya senang dengan apa yang dilakukannya dan puas terhadap prestasi yang telah didapatinya.

Hal seperti inilah yang selalu harus digalakkan oleh seorang guru sehingga akan terjalin hubungan yang harmonis antara guru dan siswanya. Keharmonisan hubungan antara guru dan siswanya akan memberikan dampak yang positif terhadap interaksi pedagogis antara guru dan murid. Selain itu seorang guru juga harus memberikan pemahaman kepada peserta didik bahwa reward yang diberikan hanyalah untuk memotivasi mereka supaya belajarnya lebih giat lagi.

Kemudian guru juga harus menanamkan dalam dirinya bahwa pemberian reward tersebut hanya karena guru menginginkan anak didiknya rajin, ulet, giat dalam belajar untuk meraih prestasi. Jika peserta didik berprestasi dalam belajar, maka tujuan pembelajaran dan sekolah telah tercapai.
Sebaliknya, jika dalam memberikan reward tersebut terdapat tujuan-tujuan yang lain, maka sudah dapat dipastikan tujuan tersebuat akan memberikan implikasi yang negatif dan hal semacam itulah yang akan merusak sistem pendidikan kita.

Pemberian reward kepada siswa juga dapat berdampak negatif bagi siswa jika guru tidak memperhatikan kaedahkaedah dalam pemberian reward tersebut.

Oemar Hamalik dalam Akyuni mengatakan bahwa reward akan memiliki dampak yang negatif terhadap siswa jika; Pertama jika reward tersebut sudah dijadikan tujuan oleh siswa, sehingga tujuan utama dari proses pembelajaran tersebut telah dikesampingkannya. Hal seperti inilah yang menjadikan generasi kita generasi yang beroriantasi pada kebendaan. Kedua, Guru memberikan reward kepada siswa tidak atas dasar yang sama, padahal prestasi yang dicapai siswa adalah sama. hal ini akan mengakibatkan kecemburuan siswa dan akan menimbulkan prasangka bahwa guru tersebut memiliki sifat pilih kasih (Akyuni, 2013: 58).

Untuk meminimalisir dampak negatif dalam pemberian reward maka seorang guru perlu untuk memperhatikan beberapa hal; Pertama, pemberian reward kepada siswa hendaknya berdasarkan apa yang dikerjakannya bukan berdasarkan siapa yang mengerjakan. Artinya siswa dari golongan manapun ketika dia melakukan suatu perbuatan baik maka dia berhak untuk mendapatkan reward walaupun mungkin siswa tersebut dalam pandangan guru adalah siswa yang "bermasalah". Kedua, pemberian reward oleh seorang guru harus memiliki batasan. Artinya reward bukanlah suatu metode yang harus digunakan oleh guru secara terus menerus. Penggunaan secara terus menerus akan mengakibatkan reward menjadi tujuan seperti yang telah 
disinggung diatas. Ketiga, Guru tidak hanya melihat hasil akan tetapi juga harus menghargai proses yang telah dijalani oleh siswa. Seorang siswa yang dinilai telah melakukan proses dengan benar dan sungguh-sungguh, walaupun dia belum mendapatkan hasil yang memuaskan juga harus menjadi perhatian seorang guru. Sehingga siswa merasa apa yang telah dilakukannya tersebut dihargai oleh gurunya (Rakhil, 2015: 37).

Reward yang diberikan dengan baik juga akan memiliki dampak yang positif bagi perkembangan anak didik. Peserta didik akan mendapatkan ketentraman batin serta perasaan puas terhadap apa yang dilakukannya baik secara proses maupun hasil.

Seperti yang dijelaskan di atas sebelumnya bahwa reward memiliki fungsi sebagai motivasi bagi peserta didik. Selain berfungsi sebagai motivasi, disisi lain reward juga mengambil peran sebagai penyadaran kepada peserta didik bahwa apa yang telah dilakukannya tersebut adalah benar adanya. Sehingga apa yang telah dilakukan tersebut harus selalu diulang-ulang kapan saja dan dimana saja.

Dengan demikian ada perasaan bangga pada diri siswa jika dia telah berbuat kebaikan. Walaupun perasaan bangga tersebut tidak perlu untuk ditunjukkan kepada orang lain.

Setidaknya dengan pemberian reward tersebut siswa menyadari apa yang telah dilakukan tersebut adalah benar dan dia harus mengulang-ulang perbuatan yang baik tersebut yang pada akhirnya dapat menjadi contoh bagi siswa yang lainnya.

\section{Punisment dalam Pendidikan Islam}

Punishment atau hukuman dapat diartikan dengan suatu konsekuensi logis berupa sebuah hukuman yang akan diterima seseorang disebabkan oleh halhal yang kurang baik yang telah dilakukan oleh seseorang (Baroroh, 2018: 55).
Dalam Islam term punishment diungkapkan dengan kata-kata 'Iqab, 'adzab, yang mana hal tersebut menunjukkan suatu hukuman ataupun azab sebagai bentuk pembalasan atas suatu kesalahan ataupun pelanggaran yang dilakukan terhadap suatu peraturan (Setiawan, 2018: 192).

Al-Ghazali dalam Muhammad Fauzi mengatakan bahwa hukuman adalah suatu perbuatan yang dilakukan dengan sadar yang mana perbuatan tersebut adalah perbuatan yang dijatuhkan kepada sesorang dengan tujuan menjadikannya sadar atas kelalaian yang diperbuatnya dengan tujuan perbaikan bagi yang bersangkutan (Fauzi, 2016: 34).

Dalam dunia pendidikan, hukuman adalah jalan terakhir yang dilakukan oleh guru disaat siswanya melakukan suatu kelalaian ataupun kesalahan.

Seorang guru hendaknya mengajak berdialog terlebih dahulu kepada siswa yang berbuat suatu pelanggaran ataupun kesalahan. Dengan adanya dialog yang dilakukan guru kepada siswa maka siswa merasa tidak dihakimi atas perbuatan salah yang telah dilakukannya. Selain itu dengan dialog tersebut guru akan dapat menemukan penyebab siswa melakukan suatu pelanggaran dan memberikan suatu solusi atas apa yang sedang dialami oleh siswa tersebut. Disaat pendekatan yang dilakukan oleh seorang guru tidak berdampak positif pada prilaku siswa, maka seorang guru dapat memberikan suatu hukuman yang mendidik dan menyadarkan kepada siswa apa yang diperbuatnya tersebut adalah sesuatu yang salah.

Hukuman yang diberikan guru kepada siswa adalah murni untuk menyadarkan peserta didik tersebut bahwa apa yang ia lakukan sudah keluar dari ketentuan. Hukuman yang diberikan merupakan konsekuensi dari perbuatan salah mereka. Hukuman yang diberikan tersebut juga diharapkan mampu menyadarkan pelakunya supaya mereka 
tidak lagi mengulangi kesalahan yang sama kedua kalinya.

Pemberian hukuman atas suatu kesalahan akan memberikan suatu pembelajaran bahwa setiap yang dilakukan di dunia ini akan dipertanggungjawabkan baik dihadapan Allah SWT ataupun dihadapan manusia.

Dalam memberikan sebuah hukuman, seorang guru hendaknya menyertainya dengan nilai-nilai pada diri anak didik, seperti nilai-nilai tanggung jawab, disiplin dan keberhati-hatian dalam berbuat dan juga bertindak.

Dengan demikian hukuman tidak selalu dipandang buruk dan negatif. Karena dibalik sebuah hukuman ada nilainilai positif jika hukuman tersebut dilakukan dengan cara baik dan benar.

Hukuman yang dilakukan secara positif berimplikasi baik pada siswa yang menerima hukuman tersebut walaupun secara kasat mata hukuman tersebut memberikan rasa yang tidak menyenangkan bagi orang yang menerima hukuman tersebut.

Asma Hasan dalam Wahyudi Setiawan mengatakan bahwa tujuan hukuman dalam pendidikan Islam adalah mengandung hal-hal yang positif. dikatakan hukuman tersebut mengandung hal-hal yang positif karena tujuan hukuman tersebut adalah untuk perbaikan dan pengarahan kepada hal yang lebih baik, bukan didasarkan atas balas dendam ( Setiawan, 2018: 140).

Punishment ataupun hukuman yang dilakukan atas dasar balas dendam akan menghilangkan sendi-sendi kemanusiaan yang pada akhirnya akan menjadikan pendidikan tersebut sebuah wadah kekerasan bukan lagi sebagi wadah pendidikan.

Dalam pendidikan Islam diberlakukannya suatu hukuman kepada peserta didik yang bersalah merupakan suatu pencegahan agar yang bersangkutan tidak mengulangi kesalahan yang sama. Selain sebagai suatu upaya pencegahan, hukuman tersebut juga menyadarkan kepada pelaku bahwa apa yang telah diperbuatnya adalah suatu yang salah dan tidak dapat dibenarkan oleh syariat agama dan juga tatanan sosial kemasyarakatan.

Hukuman juga bisa dijadikan i'tibar bersama. Hukuman dapat dijadikan pelajaran bersama bagi siswa yang lain bahwa suatu kesalahan tersebut akan memiliki dampak negatif jika dilakukan dan akan merugikan diri sendiri ataupun orang lain jika kesalahan tersebut tidak segera dihentikan dan juga disadari.

Agar punishment tersebut tidak berakibat fatal dan negatif, dalam pelaksanaan punishment tersebut haruslah mengikuti rambu-rambu yang telah ditetapkan oleh agama dan nilainilai kemanusiaan yang ada.

Jika pelaksanaan punishment tersebut melanggar rambu-rambu yang telah ditetapkan oleh agama dan nilainilai kemanusiaan, maka punishment yang dilakukan oleh seorang guru tersebut akan menghasilkan sesuatu yang negatif dan tidak akan mengenai sasaran yang diinginkan.

Punishment yang diberikan kepada siswa hendaklah tidak membuat siswa mengalami trauma psikis. Guru jangan sampai memberikan hukuman yang membuat seorang anak menjadi trauma sehingga mempengaruhi psikologis anak tersebut. Cacian ataupun makian di depan umum tidak baik, karena dapat mempengaruhi kepribadiannya. Bentuk punishment seperti ini tidak akan menyadarkan seorang anak akan kesalahannya. Bahkan mungkin akan menimbulkan permasalahan yang lain antara guru dan anak tersebut. Anak akan menjadi seorang pendendam dikarenakan harga dirinya telah dilecehkan.

Dalam pemberian punishment hendaknya tidak melebihi dari kesalahan yang telah diperbuat oleh anak didik. Hal inilah yang diisyaratkan dalam Al-Quran 
bahwa Allah SWT tidak memberi balasan atau 'iqob yang melebihi dari apa yang diperbuat oleh hambanya. Firman Allah SWT:
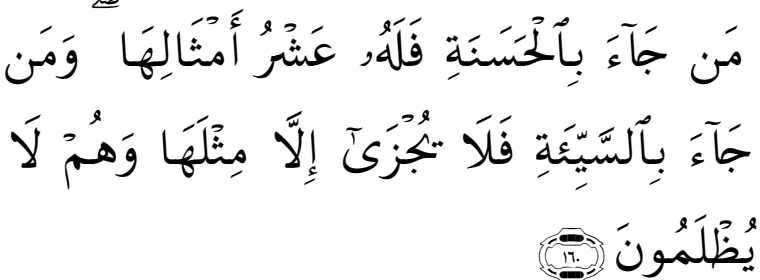

"Barangsiapa membawa amal yang baik, Maka baginya (pahala) sepuluh kali lipat amalnya; dan Barangsiapa yang membawa perbuatan jahat Maka Dia tidak diberi pembalasan melainkan seimbang dengan kejahatannya, sedang mereka sedikitpun tidak dianiaya (dirugikan)".

Ayat ini mengisyaratkan kepada kita bahwa ketika kita memberi reward kepada anak didik, maka reward tersebut boleh kita berikan sesuai ataupun lebih dari apa yang telah diperbuat oleh anak didik tersebut. Akan tetapi dalam pemberiam punishment, maka hukuman ataupun punishment tersebut harus sesuai dengan apa yang telah diperbuat oleh anak didik tersebut.

Pemberian hukuman yang melebihi dari apa yang dilakukan akan menimbulkan pemberontakan dalam jiwa peserta didik. Hal tersebut akan mengakibatkan pembangkangan yang lebih besar lagi dan juga mengakibatkan tujuan dari punishment tersebut tidak akan tercapai.

Sebelum pelaksaan ataupun penjatuhan sebuah hukuman, guru harus dapat menyadarkan kepada peserta didik bahwa apa yang dilakukannya tersebut adalah sebuah kesalahan dan sebuah pelanggaran (Rusdiana Hamid, 2006: 73).

Jika peserta didik tidak disadarkan akan kesalahan yang diperbuat tersebut, maka penjatuhan sanksi ataupun punishment tersebut tidak akan menimbulkan efek jera pada pelaku. Padahal tujuan utama dari sebuah punishment adalah pencegahan dan sekaligus untuk memberikan efek jera.

Jika siswa telah menyadari kesalahan yang diperbuatnya maka siswa tersebut akan menjalani hukuman yang diberikan kepadanya dengan sepenuh hati. Dia akan menyadari bahwa hukuman yang dijatuhkan tersebut bukanlah hukuman yang dilandasi dengan sebuah kebencian, akan tetapi hukuman tersebut murni untuk kebaikan dirinya dimasa kini dan yang akan datang.

Dalam penjatuhan sebuah sanksi ataupun punishment hendaknya seorang guru dalam keadaan tenang dan tidak dalam keadaan emosi. pengendalian emosi ini sangat penting dilakukan agar hukuman yang diberikan kepada siswa tersebut tidak diluar batas kewajaran.

Guru harus tetap meyakini bahwa siswa yang melakukan kesalahan tersebut adalah anak didiknya yang masih membutuhkan bimbingan dan nasehat darinya. Sehingga hal tersebut akan tetap menimbulkan cinta dan kasih sayang guru tersebut kepada anak didiknya walaupun pada saat yang bersamaan anak tersebut berbuat sebuah kesalahan.

Penjatuhan hukuman dalam keadaan emosi akan menghilangkan nilainilai pendidikan dalam punishment tersebut. Pada saat inilah terkadang kita menemukan sebuah punishment yang diberikan guru yang "tidak masuk akal" dan juga tidak mendidik. Sehingga punishment merupakan suatu yang sangat menakutkan dan menimbulkan efek psikologis yang negatif bagi siswa.

Untuk menghindari hal tersebut diupayakan yang menjatuhkan punishment kepada anak didik tersebut adalah orang yang benar-benar mempunyai kelembutan hati yang lebih dan sangat mencintai peserta didik. Jika punishment tersebut dilakukan oleh orang yang dalam keadaan emosi yang tinggi, ditakutkan bukanlah punishment yang diberikan melainkan karena balas dendam. 


\section{Urgensi Punishmet dalam Pendidikan Islam}

Dalam pemberian punishment atapun hukuman, seorang guru harus harus memperhatikan situasi dan kondisi kepribadian peserta didik (Ngalim Purwanto, 1985: 245). Seorang peserta didik yang memiliki kepribadian yang baik, ketika dia berbuat suatu kesalahan hendaknya dibedakan terhadap seseorang yang selalu melakukan kesalahan-kesalahan. Demikian pula seorang siswa yang cukup dengan suatu isyarat dia telah menyadari kesalahannya maka seorang guru tidak perlu membesar-besarkan kesalahan yang telah diperbuat peserta didik tersebut.

Hukuman yang diberikan kepada peserta didik tersebut juga harus memiliki akhir dan batas waktu. Hukuman yang tidak memiliki batas waktu akan membuat peserta didik menanggung kesalahan sepanjang kehidupannya. Hal ini akan menjadikan peserta didik merasa selalu bersalah dihadapan pendidiknya.

Guru harus memafkan peserta didiknya sebelum ataupun sesudah punishment tersebut dijatuhkan. Pemberian maaf dari seorang guru secara tidak langsung memberikan pelajaran kepada peserta didiknya bahwa perasaan dendam adalah suatu yang dilarang dalam ajaran agama. Jika guru mampu memaafkan kesalahan peserta didik, maka dikemudian kelak peserta didik akan mencontoh apa yang diperbuat oleh gurunya tersebut. Peserta didik akan mudah memberikan maaf kepada orang yang telah berbuat salah kepada dirinya.

Kata-kata yang kurang pantas dan sopan juga harus dihilangkan dalam penjatuhan sebuah punishment. Kata-kata yang tidak baik akan menjatuhkan martabat dan wibawa guru yang bersangkutan sehingga guru akan mendapatkan penilaian negatif dari siswa tersebut dan siswa lainnya.
Agar punishment yang diberikan kepada peserta didik tersebut mendidik dan mengena sasaran, maka seorang guru harus benar-benar memperhatikan rambu-rambu yang telah ditentukan sehingga punishment tersebut dapat dijadikan suatu metode dalam pendidikan untuk mencapai tujuan pembelajaran.

\section{PENUTUP}

Reward dan punishment merupakan suatu metode dalam dunia pendidikan yang tujuannya adalah untuk memberikan motivasi agar prestasi dan minat siswa dapat ditingkatkan. Penerapan reward dan punishment dalam dunia pendidikan haruslah mengikuti aturan dan rambu-rambu yang telah ditentukan oleh agama maupun disiplin ilmu kependidikan itu sendiri. Sedangkan punishment digunakan untuk mencegah siswa dari berbuat suatu pelanggaran dan memberikan efek jera kepada siswa yang telah berbuat suatu pelanggaran. Sama halnya dengan reward, penerapan punishment hendaknya memperhatikan rambu-rambu yang ada sehingga punishment tersebut tidak menimbulkan efek yang negatif kepada peserta didik.[]

\section{DAFTAR RUJUKAN}

Akyuni, Qurrata. "Urgensi Reward dalam Pendidikan." Serambi Tarbawi 1.1 (2013).

Bafadhol, Ibrahim. "Sanksi dan Penghargaan dalam Pendidikan Islam." Edukasi Islami: Jurnal Pendidikan Islam 4.08 (2017): 15.

Baroroh, Umi. "Konsep Reward Dan Punishment Menurut Irawati Istadi (Kajian Dalam Perspektif Pendidikan Islam)." Jurnal Penelitian Agama 19.2 (2018): 4864.

Fauzi, Muhammad. "Pemberian Hukuman Dalam Perspektif Pendidikan Islam." Al-Ibrah: Jurnal Pendidikan dan Keilmuan Islam 1.1 (2016): 29-49. 
Hamid, Rusdiana. "Reward dan punishment dalam perspektif pendidikan islam." Ittihad: Jurnal Komunikasi dan Informasi Antar PTAIS-KOPERTAIS XI 4.5 (2006): 6576.

Lidinillah, Dindin Abdul Muiz. "Heuristik dalam pemecahan masalah matematika dan pembelajarannya di sekolah dasar." Jurnal Elektronik. Universitas Pendidikan Indonesia (2011): 1-11.

Purwanto, Ngalim. Ilmu Pendidikan Teoritis dan Praktis, Bandung: Remaja Karya, 1985.

Rakhil, Fajrin. "Urgensi Reward dan Punishment dalam Pendidikan Anak Perspektif Psikologi Perkembangan." Jurnal Pikir: Jurnal Studi Pendidikan dan Hukum Islam 1.1 (2015): 31-47.

Salminawati. "Implementasi Reward Dan Punishment Dalam Pembelajaran Di Madrasah Se-Kota Medan." Al-Fatih: Jurnal Pendidikan Dan Keislaman 2.1 (2019): 1-13.

Setiawan, Wahyudi. "Reward and Punishment dalam Perspektif Pendidikan Islam." Al-Murabbi 4.2 (2018): 184-201.

Zed, Mestika. Metode Penelitian Kepustakaan. Jakarta: Yayasan Obor Indonesia, 2004. 